\title{
A Plea for a Jesuit Annual Catalog Database
}

Author: Laura Madella

Source: Engaging Sources: The Tradition and Future of Collecting History in the Society of Jesus (Proceedings of the Symposium held at Boston College, June 11-13, 2019)

Edited by: Cristiano Casalini, Emanuele Colombo, and Seth Meehan

ISBN: 978-1-947617-09-4

Published by: Institute of Jesuit Sources

Originally Published: March 1, 2021

https://doi.org/10.51238/ISJS.2019.30

Provided in Open Access by the Institute for Advanced Jesuit Studies at Boston College.

The Institute of Jesuit Sources, specializes in preserving, maintaining, and expanding for scholars around the world important texts and studies in Jesuit history, spirituality, and pedagogy.

Visit our website at https://jesuitsources.bc.edu 


\title{
A Plea for a Jesuit Annual Catalog Database
}

\author{
LAURA MADELLA
}

\author{
À quelle fêtes du Printemps vert \\ nous faudra-t-il laver ce doigt souillé \\ aux poudres des archives? \\ (At what rites of green spring \\ Must we clean this finger, soiled \\ With the dust of archives?) \\ -Saint-John Perse.
}

\section{Introduction}

Digital archives allow us to study a lot, to learn a lot, and to work a lot without traveling, without getting our hands dirty. Many industrious index fingertips that lived to scroll paper files have been invited to retire since the first digital library catalogs came out. Yet while the increasing accessibility and systematization of some inquiry procedures have made research more democratic, it has also provoked debates over the physical added value of paper-based sources: seeing and touching the documents in the flesh, considering the assets to which they belong, the halls and cellars where they are lodged, not to mention the direct counseling of a skilled archivist.

This paper originated from the spring semester I spent as a fellow at Boston College in 2019 and partially accounts for a digitization project that will proceed rather differently from the way it began, even if this will simply confirm the viability of its starting premises. The project aims to create a digital, open-access, English-language, and researchable database of the Jesuit annual catalogs. But why, in particular, the annual catalogs? The reason is their content and the way they display it: information on the identity, domicile, and activity of each and every member of the Society of Jesus kept almost continuously from the late sixteenth century on, through an accurate and efficient system of accounting.

The annual catalogs have recently attracted the attention of other researchers, some of whom have attempted to convert their own data into digital boxes and provide them with digital tools. That lifted the project to another level and required that a comparison be made of the different approaches and proposals in order to optimize the potential outcome of broader cooperation among institutes. 
With regard to the original project, what remains unchanged is the aim of pouring into the database-to-be as much as possible of the Jesuit annual catalogs' data, translated into English and starting from the order's restoration. The project also aims to enable some research features that would allow scholars to filter items in space and time and apply simple formulas for sums, averages, and so on.

However, before the paper goes on to discuss the project in greater detail, it is important to clarify why those internal administrative records are so interesting and to provide some examples among the multitude of research paths to which they could apply.

\section{History of the Annual Catalogs}

The Jesuit Institutum established through time the keeping of different types of catalogs, intended as ordered lists of items. As important administrative tools, catalogs had to be in every Jesuit "administrative" unit, be it the general see, the province, or the single residences and colleges. Some catalogs were devoted to keeping track of temporal items, properties, and incomes: beyond the financial statements, for instance, the provincial administration updated a list of all the clerical benefits for which it was responsible, ${ }^{1}$ as well as a list of goods or money eventually received in deposit; ${ }^{2}$ houses and residences filled lists of the alms received and their donors; ${ }^{3}$ and colleges scheduled endowments and benefactors. ${ }^{4}$ Even more impressive, and suggestive of the Society's managerial soul, are the catalogs of people, well exemplified by the "catalog of catalogs" that was kept in every provincial archive:

Art. 23. Provide each archive with the following books, and make sure that they will be available at the right time: [...] a book containing catalogs of tertians, along with the date of probation, the assessment of each candidate on behalf of the instructor, rector, and the ministers.

A book containing the list of all the superiors in the province, along with a list of all colleges and houses.

A book containing catalogs of people admitted every year in the Society and dismissed from it, on the provincial basis.

A book containing catalogs of who received the first tonsure, the minor and major orders, along with mention of the year, day, place, and bishop who had celebrated.

\footnotetext{
${ }^{1}$ Institutum Societatis Iesu (Rome: Civilitas Catholica, 1870), 2:75.

${ }^{2}$ Institutum, 2:100.

${ }^{3}$ Institutum, 2:105.

${ }^{4}$ Institutum, 2:115.
} 
A book containing catalogs of the dead in the province [...]

A book containing triennial catalogs, the first, second, and third.

A book containing annual catalogs, that is to say, short catalogs. ${ }^{5}$

The source of this quote is the Regulae socii provincialis (Rule for the provincial secretary [1682]), ${ }^{6}$ article 23 of which provides a theoretical precondition to the empirical information I acquired while visiting the lavishly endowed archive of the Euro-Mediterranean province in Rome, ${ }^{7}$ namely that almost every single aforementioned catalog was still filled out in the restored Society during the nineteenth century and still belongs, today, to the provincial holding. ${ }^{8}$

Printed copies of annual (or short) catalogs, the focus of this paper, have been regularly kept since the first years of the restoration. Among all the catalogs of the provincial archive, only triennial and annual catalogs offer a general picture of a province because they record all its members, although following different criteria.

The centrality of those documents in the Society's governance is stated through the legislation concerning them. The duty to fill out catalogs of the members of each and every province was put forth by the Constitutions ${ }^{9}$ and then

\footnotetext{
5 "Curet igitur, ut in eo archivo sint, et mature suppleantur saltem sequenter libri. [...] Liber continens catalogum Patrum tertiae probationis, adnotato tempore, quo probati sunt, et iudicio Instructoris, Rectoris, et Ministris e singulorum satisfactione. Liber continens seriem superiorum cum provinciae, tum collegiorum, domuumque. Liber continens catalogos admissorum ad Societatem quoque anno, et dimissorum ex Societate in provincia. Liber continens catalogos initiatorum prima tonsura, Ordinibus minoribus, et maioribus, adnotatis anno, die, loco, nomine Episcopi. Liber continens catalogos admissorum ad vota simplicia, et promotorum ad gradus professionis quatuor, aut trium votorum, Coadiutorum formatorum spiritualium, et temporalium; adnotatis [...]. Liber continens catalogum mortuorum in provincia, adnotatis similiter [...]. Liber continens catalogos triennales, primum, secundum, tertium. Liber continens catalogos annuos, seu breves." Institutum, 2:96-97.

${ }^{6}$ John W. Padberg, S.J., Martin D. O'Keefe, S.J., and John L. McCarthy, S.J., eds., For Matters of Greater Moment: The First Thirty Jesuit General Congregations; A Brief History and a Translation of the Decrees (St. Louis, MO: Institute of Jesuit Sources, 1994).

${ }^{7}$ As it appears in Maria Macchi's paper, the core of the archive of Euro-Mediterranean province are the assets of the restored Society that had belonged to the Roman provincial archive in its different extensions and denominations since 1814 .

${ }^{8}$ In the Euro-Mediterranean archive, there is no sign of any triennales, which included the most sensitive (and juicy, to some extent) information.

9 "Ad clariorem omnium cognitionem, quarto quoque mense mittantur Praeposito Provinciali ex singuli domibus vel collegiis brevis catalogus, isque duplex, omnium, qui in ea domo sunt; quique etiam post ultimum catalogum missum usque ad id tempus quo scribitur, desint; vel quod mortui fuerint, vel alia quavis causa: breviter perstringendo dotes uniuscuiusque [...] Ita enim melius intelligentur, quae ad personas attinent; meliusque totum Societatis corpus ad Dei gloriam regi poterit" (Within the fourth month, each and every house or college of the province must send to the superior of the province, in two copies, the catalog of all those who dwell in that house; along with the mention of all those who, since the last catalog, are no more in that house, because they died or for any other reason: briefly describing their talents [...] so that one can better understand what concerns people; and the whole body of the Society can be better ruled, for the greater glory of God); Constitutiones, octava pars, cap. 1; Institutum Societatis Iesu (Rome: Civilitas Catholica, 1869), 1:104.
} 
established in the Second General Congregation (1563) within a wider section of rules grouped in the Formula scribendi (Writing formula). ${ }^{10}$ Articles 32 to 35 of the Formula state that the superiors of each house and college must fetch the provincial procurator two different catalogs before he leaves to meet the superior general in Rome, which happened every three years ${ }^{11}$ and is why those two main catalogs had to be drafted triennially. The first catalog listed every single member of every single house and college in the province, specifying his name, demographic data, state of health, advancement in studies, tasks in the residence, grade, and progress in the Society; the second was the so-called "secret catalog" (catalogus secretus) because it did not name the Jesuits but arranged them with the listing number provided in the first catalog, so that it could only be read and understood if consulted in the context of the latter. The Formula required the second catalog to be filled out with descriptions of members' wit, judgment, prudence, practical experience, advancement in studies, physical appearance, and "their talent for a suitable role in the Society,"12 which explains the confidential aspects of the documents, including the requirement that they be handed in person to the superior general rather than being shipped and that they carry the provincial procurator's seal. ${ }^{13}$ Needless to say, together, the two catalogs provided the superior general with a tremendous apparatus to control the human resources of his flock. ${ }^{14}$

Finally, in accordance with article 34 of the Formula, a third catalog, called brevis (short), was sent from each residence to the provincial at the end of every year, so that the provincial could in turn send it to the superior general in the January of the following year: "Toward the end of the year, a third and short catalog must be sent to the provincial containing the names and tasks of each and every member of Ours." 15

This short catalog, sometimes called the "third catalog of the persons" (catalogus tertius personarum), coincided with the annual or "short" catalog mentioned in the Rule for the Provincial, while the "triennial third" (triennalis tertius) probably referred to the so-called "third catalog of the goods" (catalogus tertius rerum) along with the "addition to the first and second catalog" (supplementum primi et

\footnotetext{
${ }^{10}$ Institutum, 2:40-44. See Annick Delfosse, "La correspondance jésuite: Communication, union et mémoire; Les enjeux de la Formula scribendi," Revue d'histoire écclesiastique 104 (2009): 97-111.

${ }^{11}$ Institutum, 2:196.

12 “Ad quae Societatis ministeria talentum habeat"; Institutum, 2:43.

${ }^{13}$ Institutum, 2:44.

${ }^{14}$ Cristiano Casalini, "Discerning Skills: Psychological Insight at the Core of Jesuit Identity," in Exploring Jesuit Distinctiveness: Interdisciplinary Perspectives on Ways of Proceeding within the Society of Jesus, ed. Robert A. Maryks (Leiden: Brill, 2016), 189-211.

15 "Sub finem cuiusque anni interiecti, tertium etiam alium brevem catalogum ad Provinciale mittant, continentem nomina, et ministeria, in quibus unusquisque nostrorum occupatur" (Institutum, 2:43-44).
} 
secondi catalogi), which are often found attached to the first and second triennales in the Archivum Romanum Societatis Iesu (ARSI). ${ }^{16}$

Decree 44 of the Second General Congregation detailed the contents of the brief catalogs: "The rectors of the colleges and the local superiors must draft once a year an orderly catalog of fathers and brothers, and further general information"17_information that could be public knowledge and the potential disclosure of which would not cause any problems. This information was orderly and methodically displayed so that it was as user-friendly as possible, with the names and demographics of the members, date of admission to the Society, residence, and task in the reporting period; a handier and condensed version of the "first catalog" (catalogus primum), some might say.

The Formula scribendi ruled the Society's written world for over two centuries and remained unmodified until 1829, when Superior General Jan Roothaan (in office 1829-53) issued a document entitled "Guidance to the Writing Formula." 18 But even then, no amendment was made to the catalogs' provisions, ${ }^{19}$ which shows that they still served the purpose just the way they were. However, over time, the catalogs' layout and settings gradually changed, and during the eighteenth century many provinces chose to print them rather than write them by hand while still maintaining the general tabular scheme.

\footnotetext{
16 "Mittant etiam supplementum primi et secundi catalogi, in quo ea tantum adnotabunt, quae eo anno de novo occurrerint addenda; ut qui in Societatem fuerint admissi, aut ab ea defuerint, vel quod mortui sint, vel alia quavis causa" (Besides, a supplement to the first and second catalog must be sent, adding information about the new year; containing the new admissions in the Society along with the new dismissals, because of death or any other reason); Institutum, 2:44.

17 "Rectores Collegiorum \& Praepositi locales catalogum Patrum ac Fratrum conficiant, \& informationem commune semel anno ordinarie" (Decreta congregationum generalium Societatis Iesu [Rome: Roman College, 1615], 138).

${ }^{18}$ Robert Danieluk, S.J., "Ob communem fructum et consolationem: La Genèse et les enjeux de l'historiographie de la Compagnie de Jésus," AHSI 57, no. 149-50 (2006): 29-52, here 50: "In the restored Society, General Jan Roothaan wrote the 'Practica quaedam ad Formulam scribendi et paradigmata informationum,' whose first edition appeared as a lithography in 1829-33. That guidance has been reprinted several times, until recent years" (Dans la Compagnie rétablie, le general Jan Roothan prépara les 'Practica quaedam ad Formulam scribendi et paradigmata informationum,' dont la premiere édition lithographiée paraîtra en 1829-1833. Cette instruction a été plusieurs fois rééditée, jusqu'à une époque très récente).

${ }^{19}$ Practica quaedam ad formulam scribendi et paradigmata informationum [Guidance to the writing formula with practical examples] (Vienna: Mekhitarist Congregation, 1856).
} 

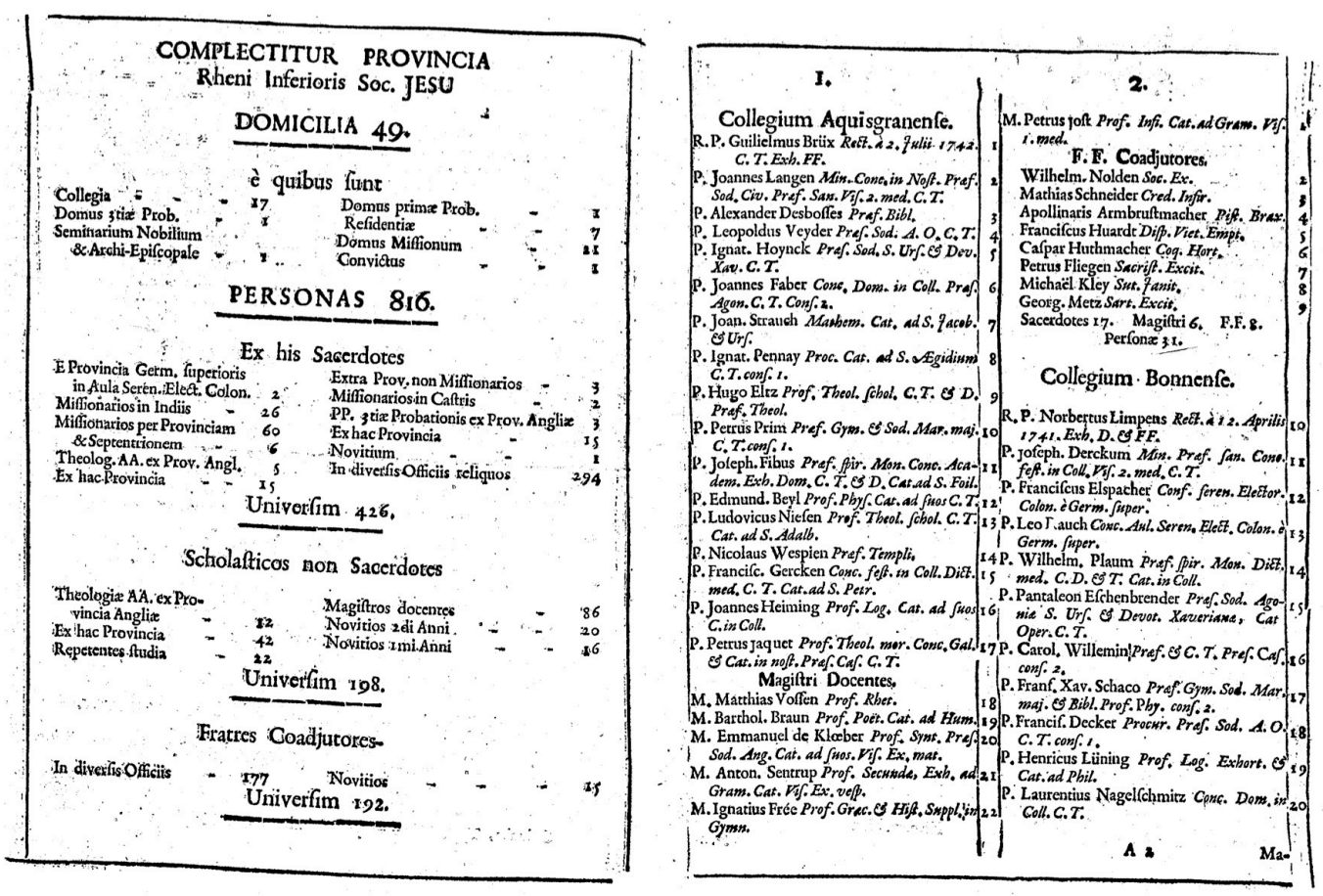

Figure 1. Pages from Catalogus personarum et officiorum provinciae Societatis Jesu ad Rhenum Inferiorem a I. Novembris anni 1743 in annum 1744 (Cologne: Drimborn, 1744).

\section{Historiography of the Annual Catalogs}

Beginning with the appearance of Monita secreta (Secret instruction [1614]), ${ }^{20}$ the Jesuits' black legend fed on the myth that the Society secretly pursued wealth and power through deceitful means, as a result of which its meticulous administrative apparatus came under suspicion. However, it was also in this period that the first seeds of critical arguments about the technical devices of Jesuit administration were also sown, since the rare historical writings mentioning Jesuits' accounting or, even more rarely, catalogs as an object to describe and not a mere source, are to be found in the milieu of the anti-Jesuit polemics of the eighteenth and nineteenth centuries. The following passage, for example, was composed in the middle of the anti-Jesuit press campaign that raged in Italy in the 1760 s:

I believe, [the Jesuit] said, that nobody makes the effort to examine the most evident things, and, for God's sake, is it so difficult to see what is self-evident? We are in Venice, Padua, Vicenza, Verona, Brescia, Belluno. I suppose there are about 120 of us, altogether [...] Neither could this be a

${ }^{20}$ Sabina Pavone, The Wily Jesuits and the Monita secreta: The Forged Secret Instructions; A History and a Translation of the Monita (St. Louis, MO: Institute of Jesuit Sources, 2005). 
sketchy count, nor can our politics counterfeit it. The prince must know it, citizens and cities can see it, we print catalogs of our members in every province, in the sunlight. ${ }^{21}$

The excerpt comes from Lettera di un uomo onesto (A honest man's letter), a supposedly anonymous missive published by the Theatine Tommaso Antonio Contin in the second edition of his controversial book Monumenti Veneti intorno i padri gesuiti (Venetian monuments of the Jesuits fathers [1763]). Among several biting writings against the order, Contin also published this letter, warmly supportive of the Society and reporting a dialogue between its unknown author and a likewise anonymous Jesuit. Needless to say, the reiterated anonymity raises more doubt about that honest man's real existence. But even though the letter was a fake, forged by Contin himself with the sole purpose of articulating a bombastic reply, ${ }^{22}$ it seems clear that annual catalogs were widely seen or promoted as providing a crystal clear portrait of the Society of Jesus, and as such they were even used as evidence in trials. $^{23}$

Free from the cumbersome chains of early modern black legends, ${ }^{24}$ researchers in the late twentieth century developed a deep interest in the Society's accounting system. To a certain extent, this line of research was encouraged by Michel Foucault's Discipline and Punishment and its examination of devices related to control and governance. At the same time, the renewed interest in the Society's accounting system was enabled by a wave of studies made possible by the refurbishment of the Jesuit archives ${ }^{25}$ as well as a focus on the history of economics and its more "technical" features from a social perspective. ${ }^{26}$ In the Jesuits'

\footnotetext{
21 "Io non credo, disse [il Gesuita], che nessuno si prenda la briga d'esaminare le cose più palpabili, ma di grazia ci vuol tanto a vedere ciò, che è sì visibile? Noi siamo in Venezia, in Padova, in Vicenza, in Verona, in Brescia, e in Belluno. Tra tutti saremo in circa cento venti: Il Conto è facile [...] Questo non credo un Conto sospetto, né che la nostra Politica possa giugnere a falsificarlo. Il Principe deve saperlo, i privati e le Città lo veggono, stampiamo, noi stessi senza riserva, un catalogo dei nostri soggetti in ogni Provincia," Tommaso Antonio Contin, Monumenti Veneti intorno i padri gesuiti (Lugano: Giuseppe Bettinelli, 1763), 165-66.

${ }_{22}$ Which he actually did in the Appendice alla prima parte dei Monumenti Veneti in risposta alla lettera di un'uomo onesto [Appendix to the first part of Venetian Monuments as a reply to A Honest Man's Letter] (Venice, 1762).

${ }^{23}$ In Victorian England, catalogs as well as extracts from the Constitutions, letters, and further provincial registers were used as pieces of evidence in the Court of Common Pleas; see, for instance, the Common Bench Reports: Cases Argued and Determined from the Court of Common Pleas (London: Benning \& Son, 1860), 6:33-34.

${ }^{24}$ Even though some prejudices are hard to kill; see, for instance, Arnaldo do Éspirito Santo, “Monita secreta: Uma mistificação que resiste," Bróteria 156, no. 1 (2003): 86-91.

${ }^{25}$ Such as Edmond Lamalle, "L'archivio di un grande ordine religioso: L'Archivio Generale della Compagnia di Gesù," Archiva ecclesiae 24/25, no. 1 (1981-82): 89-120.

${ }^{26}$ Also focused on religious institutions: Miguel Batllori, Cultura e finanze: Studi sulla storia dei gesuiti da S. Ignazio al Vaticano II (Rome: Edizioni di Storia e Letteratura, 1983); Richard C.
} 
meticulous administrative practices, scholars began to glimpse a system that went far beyond the customary need to allocate, handle, and monitor resources, beyond the strictly economic purpose for which those practices had been created-even if the economic purpose was usually achieved.

Paolo Quattrone links the Society's recording apparatus to the hierarchy of the Society itself in the sixteenth and seventeenth centuries - a hierarchy where the absolute ruler was neither the superior general nor the pope, but God. Quattrone read the accounting of the Sicilian province in the light of a treatise of double-entry bookkeeping ${ }^{27}$ written by the Jesuit Ludovico Flori in 1636, Trattato del modo di tenere il libro doppio domestico col suo esemplare (Treatise on how to keep the double-entry, along with an example) ${ }^{28}$ and infers that the accounting methodology contained "the same attention towards differentiation and dedifferentiation [...] as did the Ratio and the Spiritual Exercises [...] an effective combination of analysis and synthesis." 29

The individual recording practices of the Exercises, where "the absolutism of God is fused with the individualism of the self," acted as a model in shaping all further recording practices, which led to similar graphic and numeric representations for different categories of information.

As for the Sicilian archive, Quattrone identified an "accounting for the college," which was purely economic, ${ }^{30}$ and an "accounting for the soul," that is, depictions of the character of every Jesuit recorded in the second triennial catalog. All the more reason why the annual catalogs represented an "accounting for the people," the "accounting for the people" par excellence.

Most of the information in the short catalogs is the same as the catalogus primus - the members' identity and their roles in the Society - but it was displayed differently. The concise nature of the annual catalogs was achieved through the layout of a ledger and followed the distinctive accounting principle of double recording (the double entry). From a province's short catalog, the hierarchy of a single residence can be visualized because the list of its members usually starts with the superior, followed by the procurators and counselors, and then down according

Laughlin, "Accounting in Its Social Context: An Analysis of the Accounting Systems of the Church of England," Accounting, Auditing \& Accountability Journal 1, no. 2 (December 1988): 19-42.

${ }^{27}$ Double-entry bookkeeping is an ancient system of administrative recording that has become the basis of financial and economic recording all over the world. Probably perfected in East Asia during the early medieval period, the system requires every item to have two equal and corresponding accounts, belonging to two different criteria, financial and economic.

${ }^{28}$ Trattato del modo di tenere il libro doppio domestico col suo esemplare: Composto dal Padre Lodovico Flori della Compagnia di Giesù (Rome: Lazzari Varese, 1636).

${ }^{29}$ Paolo Quattrone, "Accounting for God: Accounting and Accountability Practices in the Society of Jesus (Italy, XVI-XVII Century)," Accounting, Organizations and Society 29 (2004): 647-83, here 664.

${ }^{30}$ Quattrone, "Accounting for God," 663-66. 
to the dignity of the role: fathers, scholastics, novices, and temporal coadjutors. ${ }^{31}$ However, it is also possible to infer the hierarchy and composition of the province itself, as a tabular summary recapitulates all the province's houses along with their people immediately before, or immediately after, the list of members, so that every house appears on the catalog at least twice, as does the number of its members, which is summarized in every detailed list of each house and then finally (or previously) in the tabular summary, so it can be balanced and cross-checked.

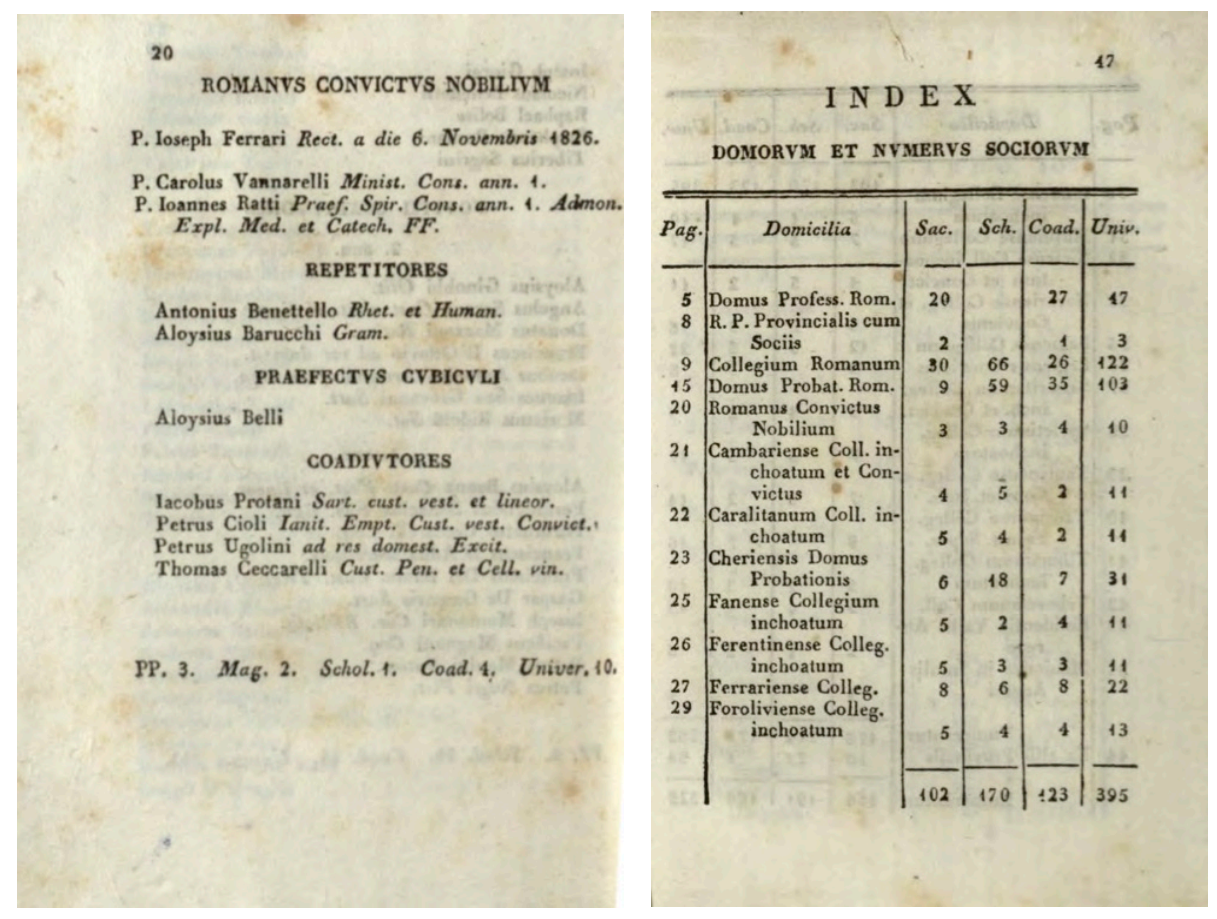

Figures 2-3. Pages from Catalogus sociorum et officiorum provinciae Italiae Societatis Jesu anno 1827 ineunte (Rome: Puccinelli, 1827).

The same applies to people's names and titles within the order: whether they were fathers, scholastics, or coadjutors is repeated both in their own residence's list and in the alphabetical tabular summary, which also records the year (or date) of birth and admission and the year (or date) of the final vows.

Annual catalogs also capture the dynamics of a province, tracking the movements from the inside out and which brothers were in mission and where, which were studying or serving abroad and where, which Jesuits were living in the province and where they came from, and who had died and where they had died, the latter of which became a further document to put aside the more specific catalogi defunctorum (catalogs of dead). Naturally, if the 1826 catalog of the province of

\footnotetext{
${ }^{31}$ In the catalogs of the new Society, spiritual coadjutors, who were ordained priests, are generally listed as "fathers." As such, "priests" is used in this paper to also refer to spiritual coadjutors, whereas "coadjutor" is exclusively used to refer to temporal coadjutors.
} 
Anglia mentions a scholastic novice as studying in Paris, Gallia's catalog of the same year records his presence as a "foreign scholastic novice," along with his demographics, title, and provenience. This way, the annual catalogs of a province were not freestanding within their own boundaries but were connected to each other, and the double entry crossed provincial borders, transforming the set of catalogs from the same year into a consolidated balance sheet.
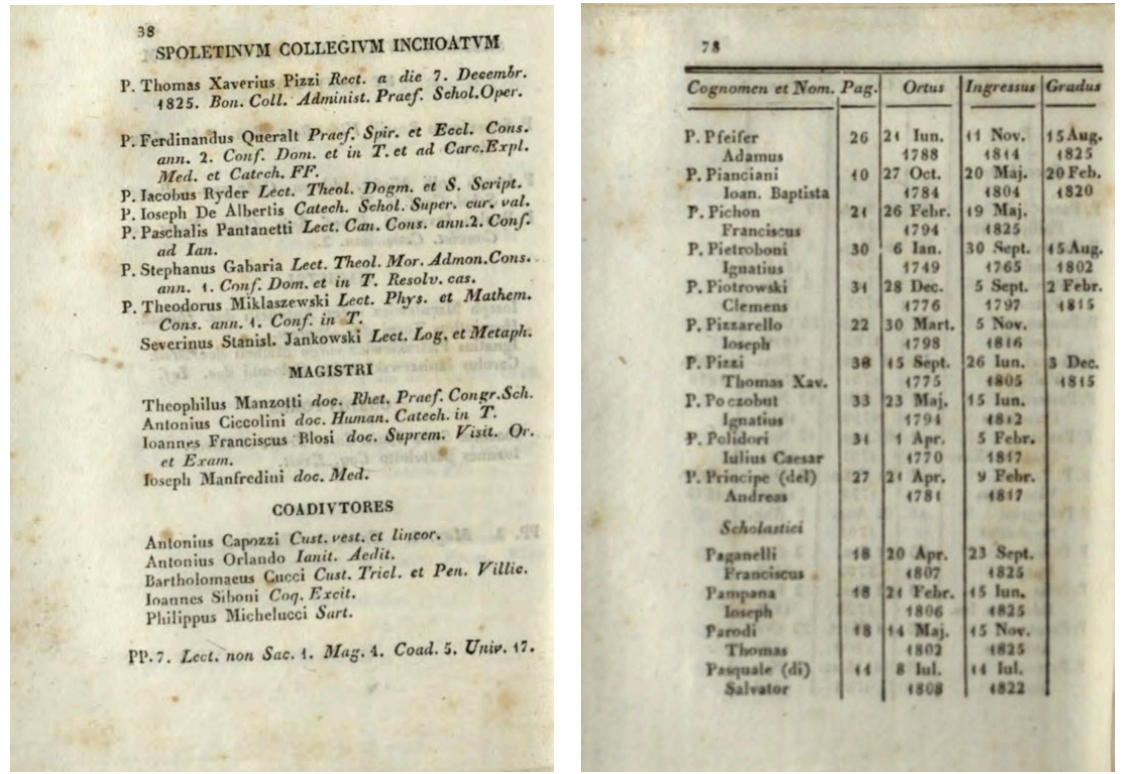

Figures 4-5. Pages from Catalogus sociorum et officiorum provinciae Italiae Societatis Jesu anno 1827 ineunte (Rome: Puccinelli, 1827).

Any other kind of catalog or accounting practice - for the house, the college, or the province, attesting inputs and outputs of goods and people, rents of properties, values of characters, and growth of souls - could be considered an extension of the basic information provided by the short annual catalogs.

\section{Perspectives from the Nineteenth Century}

The annual catalogs consequently contain an abundant amount of information that can shed important light on various periods of Jesuit history. To better illustrate and support this statement, I built a tiny sample of a database recording all the annual catalogs' data for six Jesuit provinces-Anglia, Gallia, Hispania, Italia, Neapolis, and Sicily-for the year 1826 into Excel macro spreadsheets. Among them, the province of Naples drafted a manuscript catalog 1826 exeunte ("exiting" the year 1826 ) at the end of the reference year, while the others created 1827 ineunte ("entering" the year 1827) at the beginning of the following year. 
As catalogs report all lexical information in Latin, except for people's surnames, while the database needs to be in English, I converted Latinized first names to the native language of their owner and toponyms to their actual English version. I spelled out the Latin abbreviations for the ministries and appointments and translated the Latin word using, when available, the English translation provided by Wiktor Gramatowsky, S.J.; nonetheless, many of the codified roles and tasks entrusted to Jesuits required a new translation.

Finally, I composed the following master file:

Table 1. Catalogs' Master File

\begin{tabular}{|c|c|c|c|c|c|c|c|}
\hline Title & Name & $\begin{array}{l}\text { Sur- } \\
\text { name }\end{array}$ & Birth & Admission & $\begin{array}{l}\text { Final } \\
\text { vows }\end{array}$ & Death & $\begin{array}{l}\text { Ministries and } \\
\text { tasks }\end{array}$ \\
\hline priest & Antonio & Alcoriza & $\begin{array}{l}23- \\
\text { mar- } \\
1742\end{array}$ & $\begin{array}{l}28 \text {-sept- } \\
1757\end{array}$ & $\begin{array}{l}15- \\
\text { aug- } \\
1805\end{array}$ & & master of novices \\
\hline priest & Juan & Riera & $\begin{array}{l}14- \\
\text { sept- } \\
1799\end{array}$ & $\begin{array}{l}03 \text {-mar- } \\
1817\end{array}$ & & & $\begin{array}{l}\text { master of novices } \\
\text { assistant }\end{array}$ \\
\hline priest & Miguel & Garcías & $\begin{array}{l}10- \\
\text { dec- } \\
1785\end{array}$ & $\begin{array}{l}31-\text { dec- } \\
1817\end{array}$ & & & minister \\
\hline priest & $\begin{array}{l}\text { Mauri- } \\
\text { cio }\end{array}$ & Sánchez & $\begin{array}{l}23- \\
\text { sept- } \\
1800\end{array}$ & 28-apr-1817 & & & procurator \\
\hline priest & Juan & Tolrá & $\begin{array}{l}09- \\
\text { may- } \\
1739\end{array}$ & $\begin{array}{l}15 \text {-may- } \\
1753\end{array}$ & $\begin{array}{l}02- \\
\text { jan- } \\
1772\end{array}$ & & senior, nurse \\
\hline priest & Mariano & Puyal & $\begin{array}{l}14- \\
\text { oct- } \\
1792\end{array}$ & $\begin{array}{l}18-m a r- \\
1816\end{array}$ & $\begin{array}{l}15- \\
\text { aug- } \\
1826\end{array}$ & & $\begin{array}{l}\text { instructor of the } \\
\text { prince }\end{array}$ \\
\hline priest & Manuel & Gil & $\begin{array}{l}04- \\
\text { jan- } \\
1794\end{array}$ & $\begin{array}{l}24-\text { mar- } \\
1816\end{array}$ & $\begin{array}{l}15- \\
\text { aug- } \\
1826\end{array}$ & & $\begin{array}{l}\text { professor of } \\
\text { maths, spiritual } \\
\text { director in the } \\
\text { military college } \\
\text { of Segovia }\end{array}$ \\
\hline priest & José & Alcalde & $\begin{array}{l}22- \\
\text { apr- } \\
1787\end{array}$ & 20-jan-1819 & & & procurator \\
\hline priest & $\begin{array}{l}\text { Pablo } \\
\text { Primo }\end{array}$ & Romero & $\begin{array}{l}09- \\
\text { jun- } \\
1795\end{array}$ & $\begin{array}{l}02-\text { dec- } \\
1825\end{array}$ & & & novice \\
\hline $\begin{array}{l}\text { scholas- } \\
\text { tic }\end{array}$ & Vicente & Morera & $\begin{array}{l}21- \\
\text { mar- } \\
1803\end{array}$ & 04-jun-1824 & & & chief of novices \\
\hline
\end{tabular}


One immediate insight that such data can offer by applying simple algebraic formulas to demographics after having coded and queried them concerns the Society's composition and the distribution of its human resources. How many Jesuits were in a province? How many of them were priests, scholastics, or coadjutors, and how many left their residence to study or serve outside the province? How many were novices, and at what age did they enter the order? How many Jesuits took the final vows (gradus) and at what age? Were they priests or coadjutors? How old, or how young, was the Society in 1826 ? 
Table 2. Distribution of the Jesuits in the Provinces (1826)

\begin{tabular}{|c|c|c|c|c|c|c|c|}
\hline & England & France & Spain & $\begin{array}{c}\text { Italy } \\
\text { (includes } \\
\text { Rome) }\end{array}$ & Naples & Sicily & General \\
\hline Priests & 55 & 139 & 60 & 168 & 24 & 67 & 513 \\
\hline From outside the province & 0 & 3 & 0 & 10 & 0 & 0 & 13 \\
\hline Out of the province & 39 & 4 & 3 & 0 & 0 & 8 & 54 \\
\hline Living in the province & 16 & 135 & 57 & 168 & 24 & 59 & 459 \\
\hline$\%$ & 45.71 & 30.13 & 22.44 & 31.88 & 24.74 & 35.54 & 30.06 \\
\hline Scholastics & 39 & 181 & 100 & 191 & 49 & 50 & 610 \\
\hline From outside the province & 0 & 21 & 0 & 23 & 0 & 3 & 47 \\
\hline Out of the province & 29 & 2 & 0 & 0 & 0 & 3 & 34 \\
\hline Living in the province & 10 & 179 & 100 & 191 & 49 & 47 & 576 \\
\hline$\%$ & 28.57 & 39.96 & 39.37 & 36.24 & 50.52 & 28.31 & 37.72 \\
\hline Coadjutors & 9 & 134 & 98 & 169 & 24 & 61 & 495 \\
\hline From outside the province & 0 & 0 & 0 & 1 & 0 & 0 & 1 \\
\hline Out of the province & 0 & 0 & 1 & 1 & 0 & 1 & 3 \\
\hline Living in the province & 9 & 134 & 97 & 168 & 24 & 60 & 492 \\
\hline \% & 25.71 & 29.91 & 38.19 & 31.88 & 24.74 & 36.14 & 32.22 \\
\hline Jesuits living in the prov- & 35 & 448 & 254 & 527 & 97 & 166 & 1527 \\
\hline ince & 2.29 & 29.34 & 16.63 & 34.51 & 6.35 & 10.87 & 100.00 \\
\hline
\end{tabular}


Table 3. The Mobility of the Jesuits through the Provinces (1826)

\begin{tabular}{|l|l|l|l|l|l|l|l|}
\hline & England & France & Spain & $\begin{array}{l}\text { Italy (in- } \\
\text { cludes } \\
\text { Rome) }\end{array}$ & Naples & Sicily & General \\
\hline $\begin{array}{c}\text { Novices (priests, scholastics } \\
\text { or coadjutors) }\end{array}$ & 12 & 107 & 80 & 94 & 40 & 16 & 349 \\
\hline From outside the province & 0 & 10 & 0 & 4 & 0 & 0 & 14 \\
\hline Out of the province & 12 & 1 & 0 & 0 & 0 & 0 & 13 \\
\hline Living in the province & 0 & 106 & 80 & 94 & 40 & 16 & 336 \\
\hline$\%$ ref. all Jesuits & 0.00 & 23.66 & 31.50 & 17.84 & 41.24 & 9.64 & 22.00 \\
\hline Priests with final vows & $/$ & 35 & 18 & 71 & 7 & 21 & 152 \\
\hline \% ref. priests & & 25.93 & 31.58 & 42.26 & 29.17 & 35.59 & 33.12 \\
\hline Coadjutors with final vows & $/$ & 19 & 0 & 52 & 1 & 26 & 98 \\
\hline$\%$ ref. coadjutors & & 14.18 & 0.00 & 30.95 & 4.17 & 43.33 & 19.92 \\
\hline In mission & 39 & 0 & 0 & 1 & 0 & 0 & 40 \\
\hline Out of province for studies & 29 & 6 & 3 & 0 & 0 & 11 & 49 \\
\hline
\end{tabular}

Table 4. Average Age of the Jesuits (1826)

\begin{tabular}{|l|l|l|l|l|l|l|}
\hline & England & France & Spain & Italy & Naples & Sicily \\
\hline All Jesuits & not available & 32 & 30 & 32 & 26 & 35 \\
\hline Priests & not available & 39 & 46 & 42 & 38 & 41 \\
\hline Scholastics & not available & 25 & 21 & 23 & 20 & 20 \\
\hline Coadjutors & not available & 39 & 30 & 35 & 29 & 45 \\
\hline Novices & not available & 24 & 21 & 21 & 20 & 15 \\
\hline Average age at the admission & not available & 26 & 22 & 23 & 22 & 22 \\
\hline Average age at the final vows & not available & 49 & 58 & 41 & 40 & 42 \\
\hline
\end{tabular}


The limited numeric samples of the tables above provide some interesting information. In England, the proportion of priests and scholastics was inverted in comparison with other provinces, with many more priests and fewer scholastics, the latter mostly studying abroad. The greatest number of external members was in the French province, most of whom were scholastics and novices studying in Dole and Mont-Rouge. The province also had the highest average age for the scholastics, probably a consequence of boys entering the Society later in France than elsewhere (twenty-six years old, in contrast to the twenty-two or twenty-three of Spain and the Italian territories).

Spain claimed the highest rate of scholastics, all of whom were entrusted with teaching and learning positions within the Spanish province, as there is no mention of members coming from other provinces, and only three priests were living abroad - other catalogs state that they were in Rome, Sicily, and Naples. The Neapolitan province seemed to follow the Spanish model: many scholastics, but no one from outside the province or who had traveled from the province to somewhere else. The high rate of novices (forty-one percent) reduced the average age of the province to twenty-six years, making Naples the youngest among those six. One particular detail was especially interesting: the average age of the young men upon their admission into the order was somewhat higher than the novices' age in every province. As such, it would be useful to inquire whether the enrollment of younger men was a deliberate policy of the restored Society in those years.

Each of the provinces led its members to their final vows in different ways, and most Jesuits never took them. The highest rate of priests and coadjutors with the fourth vows was found in the Italian province (forty-two percent and thirty-five percent), where they were also the youngest (forty-one years old): Did this result from the need to assign more "qualified" offices to Rome and its surroundings? In Spain, on the other hand, Jesuit priests took the vows at a much older age, while none of the coadjutors took them. Filtering the date of the final vows, it is clear that a large number of priests and brothers made vows on specific Catholic celebrations: February 2 (Presentation of Jesus at the Temple), March 25 (Annunciation to the Blessed Mary), August 15 (Assumption of Mary), and December 8 (Immaculate Conception). However, there are also some dates that fail to correspond to any specific celebrations and would benefit from further explanation. On April 3, 1826, for example, twelve priests took their final vows in Spain, France, and Italy, eight days after Easter, on Monday, a date that was never used anywhere else. One possibility is that the timing of the vows corresponds to the martyrdom of Robert Middleton and Thurstan Hunt on April 3, 1601, yet the church only beatified them in 1987and even though it is acknowledged that they were commemorated and worshipped in the nineteenth century, there is little evidence to suggest it was a tradition. 
The date of admission was often symbolic as well: many young boys entered the order on their birthday or together with a brother or a relative. Nicola (b.1778) and Giovanni (b.1775) Grassi, in the Italian province, for example, were both admitted to the Society on November 16, 1799. Giovanni took his final vows very young, at thirty-seven, and in 1826, he was already rector of the college and noble boarding school in Turin. Augustine and Théodore Combalot were twins, born August 21, 1797, and both entered the Society in France on January 24, 1825. In 1826, Augustine was a coadjutor in the house of Billon, working as a nurse. Meanwhile, his twin brother Théodore lived in the house of mission of Laval. He later became famous as the Abbé Combalot, an ultramontane preacher who helped Saint Marie-Eugénie de Jésus establish the Religieuses de 1'Assomption. ${ }^{32}$

The catalogs are remarkably useful for depicting the "political map" of a province over time: in 1826, France owned ten houses (including the house of Paris) and two houses of probation, one at Avignon and the other at Mont-Rouge. The Society's residences were evenly disseminated throughout France, and with the exception of the two houses mentioned above, each structure counted at least fifteen members and frequently more than twenty-five. The most populated was the house of probation in Mont-Rouge with eighty-six Jesuits, among whom there were fiftyfive scholastics. Some houses also controlled smaller houses in the neighborhoods. The situation in the Spanish province was completely different: relying on just one house of probation, six colleges, and one seminary in the whole kingdom, the Jesuits were concentrated in Madrid, where the Imperial College and house of probation contained fifty-six percent of all the Spanish Jesuits; fifty out of one hundred Spanish scholastics lived in the house of probation. This reflects the tragic circumstances surrounding the restoration under Ferdinand VII (r.1808-33), which also explains the lack of mobility revealed in the catalogs.

A final source of many potential inquiries is the representation of the Jesuits' ministries.

${ }^{32}$ Claude Laplatte, "Combalot (Théodore)," in Dictionnaire d'histoire et de géographie ecclésiastique 13 (1956): 355-57. 
Table 5. Jesuits' Tasks and Ministries

\begin{tabular}{|l|l|l|}
\hline Catalogs' short form & Complete Latin form & English translation \\
\hline aedit. & aedituus & sacristan \\
\hline aman. & amanuensis & secretary \\
\hline arcul. & arcularius & maker of chests and caskets \\
\hline artif. & artifex & servant, artisan \\
\hline barbit. & barbitarius/barbitonsor & barber \\
\hline bibl. & Bibliothecarius & librarian \\
\hline bid. & bidellus & porter \\
\hline catech. Ad carcer. & catechista ad carceres & catechist to prisoners \\
\hline catech. pueror. & catechista puerorum & catechist to children \\
\hline conc. B. M. & concionator Bonae Mortis & preacher of Good Death \\
\hline conc. in plat. & concionator in platea & street preacher \\
\hline
\end{tabular}

Thus far, I have recorded around 150 different tasks. Some were common to every province, as was their distribution among the Jesuits. Priests were usually counselors, ministers, admonitors, spiritual directors, preachers, directors of a congregation, confessors, examiners, professors, catechists, and collectors of cases of conscience; scholastics were lecturers, teachers, prefects of morality, and attendants to some coadjutors' tasks; while coadjutors served as sacristans, cooks, purchasers, bakers, gardeners, nurses, janitors, cobblers, tailors, carpenters, cloakroom attendants, and guardians.

Yet each of the provinces also has its own peculiarities: in the college of Turin, for example, several teachers and catechists at the boarding schools taught in public schools as well. This happened because Piedmont had entrusted the Jesuits with its "national" education after the 1821 riots, which required a degree in medicine and a more extensive lower-level education. In Rome, scholastics were often appointed as substitutes for priests' roles, such as preachers, theologians in the controversies, and examiners. Finally, only in Rome and Naples do we find barbers: three in Rome and three in the college of Naples. Rome also counted ten tailors: two in the Roman College, three in the house of probation, four in the professed house, and one in the nobles' college, which is likely to reflect the Roman prominence of representative duties.

Such a database will be able to accommodate hyperlinks providing further addenda about the main categories of data and pointing to texts, maps, and images. As for the political geography of the Society, it would be useful to know which area a province occupied in a given year, how that changed over time, and where exactly 
the residences were located. It would also be helpful to create a comprehensive glossary for the many different ministries, offices, and congregations. ${ }^{33}$

\section{Conclusion}

As can be seen, the insights offered in the previous paragraph would acquire a completely different significance if we could access the same information for all the extant provinces and for as many years as possible. In this respect, cooperation between several partners would be highly beneficial when uploading data. Those involved could work simultaneously (the number of strings, names, and numbers of those documents would take more than a generation to be reviewed) and ease the cross-checking on a complex transcribing and translating task that can induce errors and typos. Furthermore, even though the catalogs were written and printed in Latin, they represent all the "local" Jesuit contexts, and it would consequently be preferable for some of the partners to be masters of the languages of the province to which some of the catalogs refer, especially when it comes to proper nouns and toponyms that require transcribing and translating. Criteria should of course be set to enable the operators to be autonomous in transcribing, translating, inferring, and amending errors, while a "moderating committee" could check and solve the trickier questions.

Before starting such a massive task, the variety of questions that information is supposed to answer should be as clear as possible, because the technical design of the database depends on them. Perhaps there could be one simple question at the root: What did the Society of Jesus look like? The annual catalogs depicted it, creating an ID card through seemingly barren, bureaucratic writings - lists, charts, balances - thus providing the Jesuit timeline with a seamless list of men, deeds, places. Any further question or research issue stemming from that simple question would need to strive to learn not only what the Society looked like but what the Society was like. Identity papers are not enough to know someone, but they are essential in historical research, points of departure, waiting rooms, basecamps; and they deserve to be shared.

\footnotetext{
${ }^{33}$ The current author has already begun doing so on the basis of the glossary created to identify the Jesuits' different tasks.
} 